\title{
Role of Kinases and Phosphatases in Host-Pathogen Interactions
}

\author{
Horacio Bach \\ Department of Medicine, Division of Infectious Diseases, \\ University of British Columbia Vancouver, \\ Canada
}

\section{Introduction}

Living organisms are constantly exposed to changing environmental stimuli and insults; dynamic adaptation is crucial for survival. The ability of cells to sense their surrounding environment and respond in an appropriate manner is essential for the normal functioning of every living organism, and although cells are constantly exposed to numerous stimuli, they are usually able to accurately identify them and respond accordingly. These correct responses are based on a multitude of intracellular signalling networks that are able to decode and translate the incoming stimuli.

Rapid adaptation to a changing environment requires a fast response from the organism. Thus, organisms have developed specific pathways based on cascades of chemical reactions, which culminate in gene transcription and a fast metabolic adaptation. These rapid changes are important especially when responses have to be orchestrated from different cellular compartments. Thus it is not surprising, given the importance of signalling in the normal functioning of the host cell, that pathogens exploit host cellular signalling networks in order to optimize their infectious cycles. The final goal of pathogens is to erode host-cell functions and therefore establish a permissive niche in which they can successfully survive and replicate. Although most microorganisms invading the human body are contained by an efficient immune response, some microbes have evolved to successfully establish infection by bypassing defensive hostile environments mounted by the host.

Professional phagocytes, such as macrophages, neutrophils and dendritic cells are uniquely qualified to engulf and destroy microorganisms. These cells initiate immune responses and respond to microorganisms based on signal transduction pathways which are largely dependant on phosphorylation/dephosphorylation processes mediated by kinases/phosphatases. These signalling pathways are versatile and sophisticated regulatory mechanisms that play a central role in forming an integrated, information-processing network capable of coordinating multiple cellular processes in response to a wide spectrum of internal and external signals. Thus, this ubiquitous mechanism is responsible for the adaptation of cells to changes in the environment and is based on a cascade of events involving protein kinases.

This chapter will focus on: (a) the effects of secreted bacterial kinases and phosphatases on the progress of bacterial infections within their hosts, and (b) the involvement of virulence 
factors used by bacterial pathogens to modulate signal transduction pathways associated with the immunological response of the host. Only in the interaction of macrophages with pathogens will be explored. Mechanisms of signal transduction activated within bacteria in response to infection will not be discussed.

\section{Proteins and phospholipids involved in signalling}

\subsection{Protein kinases}

Protein kinases are enzymes that phosphorylate a protein substrate by transferring a phosphate group from a high-energy donor, such as ATP or GTP onto specific serine, threonine, and tyrosine residues of a protein substrate. As a result, the phosphorylated substrate is activated to perform either a specific activity or to continue with the transfer of the phosphate group downstream to another protein substrate initiating a cascade of reactions. To suppress the activity of phosphorylated proteins, phosphatases catalyze the reverse reaction by dephosphorylating the phosphorylated substrate, turning the protein substrates to their initial inactivated state (not phosphorylated) preparing the system for the next signalling event. Thus, kinases and phosphatases function as ON/OFF switches modulating specific signal transduction pathways.

\subsection{Phosphatidylinositol (PI) signalling}

PIs are small lipids derived from inositol and are key components of cell membranes. They participate in essential roles in a wide range of cellular processes, such as membrane dynamics, actin cytoskeleton arrangements and vesicle trafficking (Di Paolo \& De Camilli, 2006) (Table 1). The differential distribution of PIs in cell membranes is tightly regulated by localized PI kinases and phosphatases, which convert diverse PI species (Fig. 1). This dynamic diversity enables effective temporal and spatial regulation of membrane-associated signalling events.

\begin{tabular}{|l|c|c|}
\hline PI & Distribution & Functions \\
\hline $\mathrm{PI}(3 \mathrm{P})$ & Endosomes & $\begin{array}{c}\text { Endocytic membane traffic, } \\
\text { phagosome maturation, autophagy }\end{array}$ \\
\hline $\mathrm{PI}(4 \mathrm{P})$ & Golgi & Golgi trafficking \\
\hline $\mathrm{PI}(5 \mathrm{P})$ & Nucleus & Apoptosis \\
\hline $\mathrm{PI}(3,4) \mathrm{P} 2$ & Plasma membrane & Signalling, cytoskeleton dynamics \\
\hline $\mathrm{PI}(3,5) \mathrm{P} 2$ & Endosomes & Signalling, vacuole homeostasis \\
\hline $\mathrm{PI}(4,5) \mathrm{P} 2$ & Nucleus and plasma membrane & Endocytosis, cytoskeleton dynamics \\
\hline $\mathrm{PI}(3,4,5) \mathrm{P} 3$ & Plasma membrane & Signalling, cytoskeleton dynamics \\
\hline
\end{tabular}

Table 1. Functions and distribution of PIs (adapted from Rusten \& Stenmark, 2006) 
Since PIs are involved in a wide range of cellular functions, their metabolism is often targeted by bacterial virulence factors that act as PI phosphatases or PI adaptor proteins. The signalling pathway of PIs is based on the well-established hydrolysis of phosphatidylinositol 4,5-bisphosphate $\mathrm{PI}-(4,5) \mathrm{P}$ giving rise to the second messengers diacylglycerol and inositol 1,4,5-trisphosphate and the phosphorylation of PI(4,5)P2 yielding the novel lipid phosphatidylinositol 3,4,5-trisphosphate (PI(3,4,5)P3) (Fig. 1). PIs often act in concert with small GTPases to recruit cytosolic proteins to host membranes. This allows PIs and small GTPases to exert regulatory control on each other (Di Paolo \& De Camilli, 2006). PIs can bind GTPase-activating proteins (GAPs) and guanine nucleotide exchange factors (GEFs), whereas GTPases control PI metabolism by regulating PI kinases and phosphatases (Di Paolo \& De Camilli, 2006). Manipulation of this close functional interplay between PI metabolism and GTPase signalling can be observed in many bacterial infections.

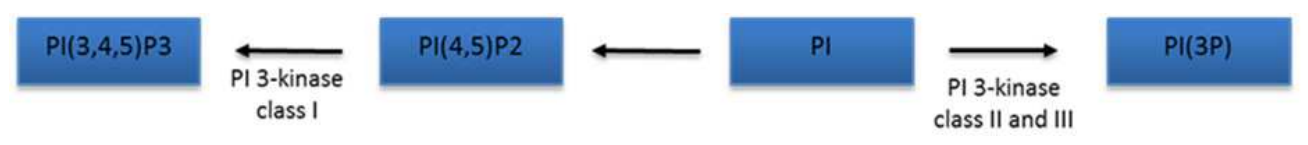

Fig. 1. Biochemical activities of PI 3-kinases.

\subsection{Small GTPases}

Proteins that hydrolyse GTP to GDP, called GTPases or G proteins, use this hydrolysis to serve a multitude of functions in the eukaryotic cells, such as actin dynamics, vesicle trafficking, phagocytosis, cell growth and cell differentiation. The Ras superfamily of small GTPases consists of several subfamilies, including the Rab, Rho, ADP-ribosylation factor (Arf), Ran, and Ras families (Sprang, 1997). Small GTPases function as molecular switches that cycle between an inactive guanosine dihosphate (GDP-bound state) and an active GTPbound state. In the active GTP-bound conformation, each small GTPase binds to a subset of downstream effectors, which in turn activate downstream proteins to generate the appropriate outcome. This cycle is facilitated by two classes of regulatory proteins: GAPs and GEFs. GAPs turn the GTPase 'off' by accelerating the intrinsic rate of GTP hydrolysis, resulting in the formation of GDP and phosphate. By contrast, GEFs turn the switch 'on' by facilitating the dissociation of GDP and allowing the more abundant GTP to bind.

\subsection{Src family}

The regulation and activity of Src family kinases (SFKs) in response to external and internal cues is important during many cellular processes including cell adhesion, migration, polarity, and division (Bromann et al., 2004). SFKs are membrane-associated enzymes that can recognize and bind their specific substrates and transfer a phosphate group onto a target protein's tyrosine residues. SKFs are regulated themselves by tyrosine phosphorylation, which controls intramolecular interactions within the molecule that fix the kinase in an inactive closed conformation, or allow the kinase to adopt an active conformation.

SFKs also activate the cytoplasmic domain of tyrosine-based immunoreceptors (Fc $\gamma$ receptors and complement receptor 3 ) once the extracellular domain binds opsonins, such as immunoglobulins $\mathrm{G}(\mathrm{IgG})$. 


\section{Microbial pattern recognition}

Since macrophages need to recognize a plethora of foreign microbes rapidly, they express a diverse repertoire of receptors that bind conserved microbial molecular patterns. These receptors have evolved to recognize molecular patterns that have remained unchanged over the evolution of the microbes. Signalling that is initiated as a result of these pattern recognition receptors increases the macrophages antimicrobial abilities. To provide a fast response against microbe invasion, mammals have developed an early immune response defined as the innate response, which does not provide a long-lasting protection, but is an essential first line of defence against bacterial pathogens.

\subsection{Pathogen-Associated Molecular Patterns (PAMPs) and receptors}

Since unchangeable molecular patterns, such as the bacterial cell wall, is essentially conserved across Gram-positive and Gram-negative bacteria, eukaryotic organisms evolved specific receptors which recognize these molecular patterns. These specific receptors are encoded by germlines and termed pattern recognition receptors (PRRs) (Ishii et al., 2008). Recognition of Pathogen-Associated Molecular patterns (PAMPs) stimulates intracellular signalling leading to gene expression and ultimately the activation of antimicrobial and inflammatory activities. Therefore, the innate response exerts two functions: (a) a rapid line of defence against pathogens, and (b) the initiation of a signalling process leading to the development of adaptive immune responses and the establishment of an immunological memory.

To avoid detection by macrophages, some bacteria have evolved to modify their cellular surface and avoid the stimulation of receptors on phagocyte membranes. For example, many Gram-negative bacteria can alter their lipopolysaccharide structure during infection, to avoid recognition or to protect themselves from antibacterial products generated by the host, such as antibacterial peptides. In parallel, the innate recognition of microbes activates a cascade of kinase reactions, which in turn, will activate a cellular response capable of eliminating the invading microorganism. Since this innate immune response can be accompanied by tissue damage, tissue repair mechanisms are also activated (Medzhitov, 2008). In addition, the activation of transcription factors represents the culmination or endpoint of many signal transduction pathways activated in response to microbial recognition. These transcription factors can access the nucleus and bind to specific DNA sequences activating gene transcription upon binding to the respective promoters or, as in the case of the IFN-B promoter, activating different transcription factors such as nuclear factor kappa B (NF-kB), interferon (IFN)-regulatory factors (IRFs) and AP-1 (Honda \& Taniguchi, 2006).

Most PRRs able to recognize bacterial patterns are Toll-like receptors (TLRs) and nucleotidebinding oligomerization domain containing proteins (NOD)-like receptors (NLRs) (Table 2). TLRs are transmembrane receptors able to recognize PAMPs in the extracellular space and in the cytoplasm or endosomes. In humans, ten TLRs have been identified (Takeuchi \& Akira, 2010). Structurally, TLRs comprise of a single membrane-spanning domain separating the cytoplasmic domain involved in signalling from the recognizing receptor able to bind the ligand. The extracellular domain is involved in PAMP recognition, whereas the cytoplasmic domain is essential for downstream signalling (O'Neill \& Bowie, 2007). TLRs are highly expressed by professional phagocytes such as macrophages and dendritic cells, but can also be expressed by other cell types, such as epithelial cells (Iwasaki \& Medzhitov, 2004). 
NLRs consist of an $\mathrm{N}^{\prime}$-terminal effector domain, responsible for downstream signalling and a $C^{\prime}$-terminal region similar to TLRs, which are involved in the PAMP recognition (Inohara \& Nunez, 2003). NOD1 and NOD2 are the best-characterized NLRs and are involved in the detection of intracellular bacteria (Chamaillard et al., 2003; Girardin et al., 2003). For instance, peptidoglycans (PGNs) are structural units of cell walls common to all bacteria (Gay \& Gangloff, 2007). Degradation of PGNs leads to the release of several structural units including muramyl dipeptide, which is sensed in the cytosol by the NLR NOD2, which in turn activates NF-kB.

\begin{tabular}{|c|c|}
\hline PAMP & PRR \\
\hline TLR2 & Lipopeptides \\
\hline & Lipoteichoic acid \\
\hline & Peptidoglycan \\
\hline TLR4 & Lipopolysaccharides \\
\hline TLR5 & Flagellin \\
\hline TLR9 & Unmethylated CpG DNA \\
\hline Diaminopimelic acid & NOD1 \\
\hline Muramyl dipeptide & NOD2 \\
\hline
\end{tabular}

Table 2. Receptors involved in bacterial pattern recognition

\subsection{Major signalling pathways involved in host-pathogen interaction}

Upon the perception of bacterial patterns, the immune response activates an intricate and complex network of kinases, which will ultimately result in the transcription of genes. The products of these genes will generate the immune response. Then, PRRs are able to activate a sequence of three major signalling pathways in mammals: mitogen-activated protein kinases (MAPKs), IRFs, and the nucler factor NF-kB, which will culminate in the transcription and release of proteins involved in the immune response.

The MAPKs are a group of protein serine/threonine kinases that are activated in mammalian cells in response to a variety of extracellular stimuli and mediate signal transduction from the cell surface to the nucleus where they can alter the phosphorylation status of specific transcription factors (Johnson \& Lapadat, 2002). Three major types of MAPK pathways have been reported so far in mammalian cells. The extracellular signalrelated kinases (ERKs 1 and 2) pathway is involved in cell proliferation and differentiation, whereas the c-Jun N-terminal kinases (JNKs 1, 2 and 3), and p38 MAPK (p38 $\alpha, \beta, \gamma$ and $\delta$ ) pathways are involved in response to stress stimuli. These three factors -ERK, JNK and p38dictate the fate of cells in concert (Johnson \& Lapadat, 2002). As an illustration, TLR4 recognizes lipopolysaccharides (LPSs) of Gram-negative bacteria. Then, when TLR4 recognizes this pattern, an activation of the MAPKs' cascade is initiated. At the onset of this process, the cytoplasmic TIR domain of TLR4 mediates the activation of the cascade through the four adaptor proteins: (a) myeloid differentiation primary response protein 88 (MyD88), (b) TIR-domain-containing adaptor inducing IFN-B (TRIF), (3) TRIF related adaptor, and (4) MyD88-adaptor-like (Mal) (Fitzgerald et al., 2001, 2003; Yamamoto et al., 2003a; 2003b). Upon activation, these adaptor proteins communicate the signal via the kinases IL-1 receptor associated kinase (IRAK)-4, IRAK-1/2, and RIPI, which in collaboration with TNF 
receptor-associated factor (TRAF) 6, activate transforming growth factor B-activated kinase (TAK) 1 in association with TAB2/3, through a mechanism dependent on the E3 ubiquitin ligase activity of the TRAF molecules (Akira \& Takeda 2004; Kawagoe et al., 2008, Sato et al., 2005). TAK1 activates IkB kinase (IKK)-alfa/beta to release NF-kB from the inhibitory subunit of IkB, as well as MAPKs (Sato et al., 2005).

\section{Phagocytosis and intracellular survival}

Upon infection, bacterial pathogens interact with host membranes through different mechanisms. The interaction between the bacterium and the host plasma membrane (and its embedded receptors) results in the activation of multiple host-signalling pathways that can alter actin cytoskeleton dynamics or vesicle trafficking. Three membrane-associated signalling events are targeted by bacterial pathogens: phosphoinositide (PI) metabolism, GTPase signalling and autophagy.

\subsection{Avoiding phagocytosis}

Some bacteria evolved to remain in the extracellular milieu to avoid being killed within the macrophage. This advantage also minimizes bacteria-macrophage interactions and as a consequence, the macrophage signalling required to activate an adaptive immune response is impaired. To avoid their engulfment, extracellular pathogens have to interfere with phagocytosis. One of the best study pathogens is Yersinia, which interferes with phagocytosis by a set of virulence proteins with an array of enzymatic activities that is delivered into macrophages. Some of the bacterial proteins interfere with the signal transduction of macrophages. For instance, YopH is a protein tyrosine phosphatase that targets host focal adhesion proteins, such as p130cas, paxillin, and focal adhesion kinase (FAK). Then, by dephosphorylating these substrates, YopH prevents uptake of bacteria by the host immune cells by destabilizing the focal adhesions involved in the internalization of bacteria by eukaryotic cells (Black et al., 1997), and allowing the pathogen to proliferate extracellularly. Yersinia also secretes YopE, a GTPase-activating protein that inactivates the small GTPases RhoA, Rac, and Cdc42 to prevent the actin polymerization that is required for phagocytosis (von Pawel-Rammingen, 2000). YopT is a papain-like cysteine protease that cleaves the lipid moiety of RhoA to depolymerize actin filaments, leading to their irreversible detachment from the plasma membrane and their inactivation (Shao et al., 2002). Thus, YopT contributes to the inhibition of bacterial phagocytosis by preventing rearrangements of the actin cytoskeleton. Yersinia also secretes the kinase YpkA into the host cytoplasm, where it phosphorylates specific proteins to prevent bacterial uptake and the killing by macrophages (Hakansson et al., 1996). Finally, YopO, a serine/threonine kinase activated by actin, contributes to the antiphagocytic activity in $Y$. enterocolitica by binding to Rho GTPases (Grosdent et al., 2002).

Other microorganisms such as enteropathogenic Escherichia coli (EPEC), target a different signalling pathway by secreting an unidentified bacterial protein into macrophages to inhibit the activity of phosphatidylinositol 3-kinase (PI3K) (Celi et al., 2001). Although pathogens that subvert macrophage phagocytic signalling remain outside the cell to avoid phagolysosomal degradation, they still have mechanisms to cope with extracellular defences, such as killing by complement or antimicrobial peptides (Wurzner, 1999). 


\subsection{Modulating the interacting membrane by disruption of PI signalling}

PIs are key players in maintaining cell membrane structure by regulating the actin cytoskeleton underneath the plasma membrane and by tagging and targeting vesicles inside the cell. The disruption of PI homeostasis at the plasma membrane can destabilize actin dynamics changing membrane morphologies, and then intracellular pathogens can modulate the membrane integrity.

The inositol phosphate phosphatase $\mathrm{IpgD}$ is an effector from the facultative intracellular pathogen Shigella flexneri that is directly translocated into host cells through a type III secretion system (Niebuhr et al., 2000). IpgD hydrolyses PI(4,5)P2 to produce PI5P, at an early stage in the infection (Niebuhr et al., 2002). The removement of PI(4,5)P2 causes a rearrangement in the cytoskeleton by changing the extent of interaction of membrane visualized as a massive cell blebbing, facilitating the invasion of bacteria (Charras \& Paluch, 2008).

Listeria invasion is mediated by interaction of the bacterial surface protein InlB with the host receptor Met receptor tyrosine kinase (Shen et al., 2000). InlB-Met interaction triggers activation, by tyrosine phosphorylation, of the Met receptor and subsequent rearrangements in the actin cytoskeleton of the mammalian cell (Mostowy \& Cossart, 2009). Ultimately, these cytoskeletal changes remodel the host cell surface, resulting in the engulfment of adherent Listeria. The human GAP ARAP2 is required for InlB-mediated cytoskeletal changes and entry of the pathogen. ARAP2 is known to bind $\mathrm{PI}(3,4,5) \mathrm{P} 3$, resulting in upregulation of a GAP domain that inactivates the mammalian GTPase Arf6 (Wong \& Isberg, 2003). Then, one of the likely ways that PI3-kinase controls entry of Listeria is through regulation of ARAP2. In addition, cholesterol-rich lipid rafts at the plasma membrane are needed for InlB-mediated uptake of Listeria (Seveau et al., 2004).

Small GTPases Sar1, Rab1 and Arf1 are required for the Legionella-containing vesicles to acquire vesicle trafficking protein Sec22b (Kagan \& Roy, 2002). Legionella secretes the effectors DrrA/SidM and LepB, which impaire the recruitment of Rab1 (Ingmundson et al., 2007). The association of these secreted effectors with the Legionella-containing vesicles surface is mediated by their affinity for the abundant lipid PI4P on the Legionella-containing vesicles surface (Brombacher et al., 2009; Ragaz et al., 2008).

SopB, a type III secretion system effector from Salmonella typhimurium, is a PI phosphatase that affects multiple processes during the course of infection, including bacterial invasion, Salmonella-containing vesicle formation and maturation (Hernandez et al., 2004). SopB hydrolyses PI $(4,5) \mathrm{P} 2$ both at the plasma membrane and on the Salmonella-containing vesicle membrane surface (Bakowski et al., 2010). Decreased levels of PI(4,5)P2 at the plasma membrane promote membrane fission by reorganizing the actin cytoskeleton during bacterial internalization (Mason et al., 2007).

SopB also mediates the production and maintenance of high levels of PI3P on the Salmonellacontaining vesicle surface through an indirect effect of its phosphatase activity. SopB recruits Rab5 and its effector VPS34, a PI3-kinase (that generates PI3P), to the Salmonellacontaining vesicle through a process that is dependent on the reduction of PI(4,5)P2 (Mallo et al., 2008). Then, by manipulating the lipid composition of the Salmonella-containing vesicle, SopB impairs the recruitment of Rabs avoiding lysosomal degradation. 


\subsection{Surviving and living within the host}

The ability to survive intracellularly is crucial for several pathogenic bacteria after they invade their eukaryotic target cells. Following engulfment by macrophages, bacteria are internalized within a membrane-bound vacuole termed a phagosome. Phagosomes are pivotal organelles in the ability of mammalian cells, including professional and nonprofessional phagocytes, to restrict the establishment and spread of infectious diseases.

Rapidly after their formation, phagosomes modify their composition by recycling plasma membrane molecules, and by acquiring markers of the early endocytic pathway such as Rab5 and EEA1 (Steele-Mortimer et al., 1999). Phagosomes have been shown to fuse sequentially with endosomes of increasing age or of increasing maturation level (Jahraus et al., 1994). A variety of Rab proteins have been identified on phagosomes, including Rab5, Rab7, and Rab11 (Desjardins et al., 1994; Cox et al., 2000).

Under normal circumstances, the phagosome progressively acidifies and ultimately, in a tightly regulated process, will fuse with the lysosome, in an event known as phagosomelysosome (phagolysosome) fusion.

The process of phagocytosis itself determines some of the characteristics of the first compartment in which pathogens are going to reside within the host cells. Newly formed phagosomes are immature organelles unable to kill and degrade microorganisms. In order to acquire and exert their microbicidal function, phagosomes must engage in a maturation process referred to as phagolysosome biogenesis. Then, to successfully invade and replicate intracellularly, pathogens must find ways to avoid the harsh environment of lysosomes, organelles containing an arsenal of potent microbicidal compounds. Therefore, the final goal of the majority of intracellular pathogens is to prevent their arrival to lysosomes, where their killing is dictated.

While the majority of bacteria grow outside of eukaryotic cells, some bacteria are facultative or even obligate intracellular pathogens; such is the case with L. monocytogenes, Mycobacterium tuberculosis, and Chlamydia trachomatis. Bacterial replication, therefore, takes place in the endosomal compartments, or in the case of Listeria in the cytoplasm due to a mechanism of escape from the phagosomes.

The life style of cytosolic bacteria can be divided into three main stages: (a) escape from the phagosome, (b) replication within the cytosol, and (c) manipulation of the innate immune responses triggered in the cytosol. The escape from the phagosome is a crucial step in the life cycle of cytosolic pathogens. This occurs rapidly following invasion, and most pathogens are detected free in the cytosol within 30 minutes of invasion. In order to evade the lysosome, a process lasting between 30-45 minutes post-engulfment (Yates et al., 2005), pathogens must escape before the fusion with lysosomes (Haas, 2007).

\subsection{Disruption of MAPK signalling pathways}

MAPK signalling is crucial for many responses to infection, representing a strategic target for bacterial subversion strategies. The extent of MAPK phosphorylation (kinase signalling kinetics) may influence the responses of macrophages. For instance, the duration of signalling through MAPK pathways determines whether a macrophage proliferates or activates in response to a stimulus (Velledor et al., 2000). Likewise, modification of MAPK 
pathways by bacteria may contribute to induction of host cell death, which is an important feature of bacterial pathogenesis, promoting bacterial tissue colonization.

In the case of $S$. enterica serovar Typhi, the tyrosine phosphatase SptP, a translocated protein from the pathogen within the host, inhibits the activation of the MAPK pathway by dephosphorylating Raf, an intermediate in this pathway (Lin et al., 2003).

A way to alter the MAPK pathway is the degradation of members involved in the response cascade. For example, Bacillus anthracis interrupts several MAPK signalling pathways by proteolytically degrading all MAPK kinases (MAPKKs) except MAPKK5. This interference is mediated by the delivery of a metalloproteinase to the cytosol, where it deactivates MEK1 by cleaving between its amino terminus and catalytic domain. Cleavage of the MAPKK that activates p38 MAPK, which is mediated by lethal factor, induces macrophage apoptosis, possibly by interfering with the p38-dependent expression of NF- $\mathrm{kB}$ target genes that are necessary for cell survival (Park et al., 2002).

Other pathogens interfere by blocking or inhibiting post-translational modifications, such as prevention of phosphorylation. Members of the genus Yersinia use an alternative mechanism to disrupt MAPK signalling and, as a result of this disruption, the downstream activation of NF-kB in macrophages is impaired. Specifically, Y. pseudotuberculosis delivers YopJ, a cysteine protease, which inhibits kinase activity by preventing phosphorylation (Orth et al., 1999). YopJ also interferes with the post-translational modification of proteins that are involved in MAPK signalling by disturbing the ubiquitin-like protein SUMO-1, and then inhibiting its conjugation to target proteins for degradation (Orth et al., 2000).

In conclusion, pathogens can modify the antibacterial response of macrophages not only towards a targeted kinase pathway, but also by the timing of the activation or inhibition.

An important downstream response of normal macrophage signalling is the production of cytokines. Cytokines are essential for modulation of inflammation, recruitment of other cells to the site of infection, and mediation of the link between innate and adaptive immune responses. As mentioned above, macrophages must control signalling that leads to inflammatory responses tightly, to avoid an inflammation dysregulation. One level of control is to regulate the intensity and duration of signalling, which often originates from TLRs. For example, the macrophage protein IRAK-M has a pivotal role in downregulating macrophage responses to LPS by inducing tolerance. Without IRAK-M, Salmonella infection causes increased tissue damage (Kobayashi et al., 2002). Another level of control is the balance between proinflammatory cytokines, such as TNF- $\alpha$ and IL-12, and predominantly anti-inflammatory cytokines, such as IL-10 and transforming growth factor- $\beta$ (TGF- $\beta$ ), which are produced during infection. Bacterial pathogens target signalling that leads to the expression of cytokine genes or their post-translational modifications that perturb the balance of cytokines to their advantage. Macrophages and bacteria can therefore both control the extent of the immune response through cytokine production.

One effector protein secreted intracellularly by Shigella is OspF, which possesses phosphothreonine lyase activity. Once translocated into the nucleus, OspF irreversibly dephosphorylates host MAPKs, and therefore prevents the phosphorylation of histone $\mathrm{H} 3$ (Li et al., 2007; Arbibe et al., 2007). Interestingly, other bacterial virulence factors, such as SpvC from S. typhimurium possess the same phosphothreonine lyase activity as OspF and also target MAP kinases of their hosts (Mazurkiewicz et al., 2008). In addition to these 
factors, the Yersinia YopJ/P effector can inactivate host MAP kinases by catalyzing their acetylation (Mittal et al., 2006; Mukherjee et al., 2006). Finally, the anthrax lethal factor, a subunit of the anthrax toxin encoded by $B$. anthracis, cleaves host MAP kinases, leading to their irreversible inactivation (Turk, 2007).

Helicobacter pylori has been reported to activate MAPK3 enzymes (Asim et al., 2010). When invading the human-derived monocyte cell line THP-1, H. pylori-stimulates the extression of IL-18 that was reduced by either ERK or p38 inhibitors (Yamauchi et al., 2008). Inhibition of ERK and, to a greater degree, inhibition of p38 have been shown to reduce H. pyloristimulated IL-8 expression in THP-1 cells (Bhattacharyya et al., 2002). Taken together, these studies suggested that at least MAPKs are involved in biological effects of $H$. pylori infection in macrophages.

\subsection{Disruption of interferon signalling}

Macrophages possess a robust tyrosine kinase signalling network that includes the Janus kinase (JAK) and the signal transducer and activator of transcription (STAT). Both pathways are activated as a result of IFN binding to their receptors on the cell surface. IFN- $\gamma$ amplifies the antibactericidal activity of macrophages (Boehm et al., 1997) by activating various enzymes within the macrophage that increase the production of damaging reactive oxygen and nitrogen species, starve the bacteria of tryptophan within the phagolysosome, and increase lysosomal degradation of the bacteria. In addition, IFN- $\gamma$ enhances the adaptive response of the organism by increasing the Major Histocompatibility Complex (MHC) class I and II antigen presentation and synthesis of cytokines such as IL-12 and TNF-a (Shtrichman \& Samuel, 2001). In conclusion, the IFN- $\gamma$ signalling network allows macrophages to respond more rapidly to bacterial infection. Bacterial impairment of IFN-ץ signalling is best characterized in macrophages infected by Mycobacteria species. M. avium infection causes a decreased transcription of the IFN- $\gamma$ receptor leading to impaired downstream STAT activation (Hussain et al., 1999). M. tuberculosis uses an uncharacterized mycobacterial surface component to affect a later step in IFN- $\gamma$ signalling. Although STAT phosphorylation, dimerization, nuclear translocation and DNA binding is intact in $M$. tuberculosis-infected macrophages, there is still a decrease in the association of STAT with transcriptional co-activators, causing an impaired transcription of IFN- $\gamma$-responsive genes (Ting et al., 1999).

\subsection{Disruption and amplification of NF-kB signalling}

NF-кB signalling relies on the targeting of its inhibitor ІкB. As a result of binding to ІкB, NF$\mathrm{KB}$ avoid translocation from the cytosol to the nucleus where it activates gene transcription. Inhibition of NF-KB signalling leads to the decreased release of proinflammatory cytokines, such as TNF- $\alpha$, and increased apoptosis, both of which can protect pathogens from the immune response.Virulence proteins secreted by pathogens such as Y. enterocolitica bind to the IKK to prevent the phosphorylation of IKB, which is essential for its degradation, thereby trapping NF-KB in the cytosol and avoiding its gene target interactions (Schesser et al., 1998). M. ulcerans inhibits nuclear translocation of NF- $\mathrm{KB}$ independently of ІкB, possibly by altering the phosphorylation of NF-KB or interfering with its DNA-binding ability (Pehleven et al., 1999). 
On the other hand, pathogens can use an opposite strategy by actively increasing the NF- $\mathrm{KB}$ activity. In this way, the production of proinflammatory cytokines can recruit more host cells to the site of infection, facilitating the bacterial spread. For instance, listeriolysin $\mathrm{O}$ and InlB, two virulence proteins secreted by L. monocytogenes, activate NF-KB in a PI3Kdependent manner. As a result of an increase in the inflammatory response, pathogens spread by recruiting more monocyte to the site of infection (Kayaal et al., 2002). Another advantage for the pathogen is a protective environment because of the anti-apoptotic signalling activated by NF-KB.

L. monocytogenes secretes InlC intracellularly, which directly interacts with the IKKa protein to block the phosphorylation of IkBa (Gouin et al., 2010). Similarly, YopJ/P, an effector produced by pathogenic Yersinia species, mediates the acetylation of the IKKa and $b$ proteins, which prevents their activation and subsequent IkBa phosphorylation (Mittal et al., 2006).

The effectors NleH1 and NleH2 of the enterohaemorrhagic E. coli (EHEC) are autophosphorylated serine/threonine kinases translocated by the pathogen. Both effectors bind directly to RPS3, a NF-kB non-Rel subunit. Although autophosphorylated, their binding to RPS3 is independent of kinase activity (Gao et al., 2009).

\subsection{Disruption of small GTPase signalling}

After initial attachment to the host cell membrane, many pathogens Gram-negative bacteria use a type III secretion system to inject virulence proteins into the host cell cytoplasm (Ghosh, 2004). A number of injected proteins bind directly to actin to modulate its dynamic leading to changes in the organization of the actin cytoskeleton (Patel \& Galan, 2005) by regulating small GTPases. In a variety of pathogens, a family of conserved type III secreted proteins influences the actin cytoskeleton dynamic by mimicking the GTP-bound form of the Rho GTPases (Alto et al., 2006). These proteins, which share no obvious sequences homology with Rho GTPases, use a conserved WxxE motif to directly activate downstream effectors of Cdc42, Rac1, and Rho (Alto et al., 2006).

Several bacterial pathogens also use the type IV secretion systems to inject effector proteins into the cytoplasm of host cells (Cascales \& Christie, 2003; Galan \& Wolf-Watz, 2006). After translocation, these effectors target various components of eukaryotic signal transduction pathways, which subvert host cell functions for the benefit of the pathogen.

Rho-family GTPases, such as Rho, Rac1, and Cdc42, regulate actin dynamics by induction of actin, lamellipodia, and filopodia formation, respectively. Inactivation of these GTPases leads to a decrease in F-actin and increase in monomeric actin (G-actin), resulting in loss of cell shape, motility, and ability to phagocytose or endocytose pathogens.

S. typhimurium manipulates this members using the effectors SopE and SptP. SopE acts as a GEF for Cdc42 and Rac1, whereas SptP acts as a GAP for Cdc42 and Rac1 (Fu \& Galan, 1999). SopE is translocated into the cell to induce actin rearrangement and membrane disruption to facilitate pathogen entry into the cell and formation of Salmonella-containing vesicles, while SptP disrupts these actin filaments to restore actin organization in the cell (Hardt et al., 1998). SptP possesses both a GAP and tyrosine phosphatase activities (Fu \& Galan, 1999). It disrupts the actin cytoskeleton by binding to Rac1 and catalysing the 
hydrolysis of GTP to GDP. Although SopE and SptP are antagonists, they are coordinately regulated. While SopE acts early in the infection to facilitate the uptake of the pathogen, SptP disasssembles F-actin organization, allowing the pathogen to proliferate in the vesicle (Kubori \& Galan, 2003).

IpgB1, a type III secretion system effector of $S$. flexneri, binds to the host cell engulfment and cell motility ELMO-DOCK180 complex activating Rac1 (Handa et al., 2007). As a result, IpgB1 increases infection efficiency. Another effector secreted by the same pathogen, IpgB2, induces membrane disruption by mimicking the Rho-GEF (Klink et al., 2010).

The effectors YopE and YopT secreted by Yersinia inhibit actin rearrangements by inactivating host Rho GTPases. YopE is known to act as a GAP (Black \& Bliska, 2000) inhibiting RhoA, Rac-1 and Cdc42 by accelerating the conversion of the GTP-bound form of the Rho GTPase to the GDP-bound inactive form. The GAP activity of YopE is also needed to prevent the formation of pores generated by insertion of the translocation machinery in the host cell plasma membrane (Viboud \& Bliska, 2001). YopT has been found previously to inhibit Rho GTPases by releasing them from the membrane (Zumbihl et al., 1999). YopT acts as a cysteine protease that cleaves the prenyl group of lipid-modified Rho GTPases (Shao et al., 2002).

The effector SidM from L. pneumophila targets Rab1 proteins involved in ER-Golgi transport. SidM is a bifunctional enzyme; the $C^{\prime}$-terminus possesses a RAB/GEF activity, whereas the $\mathrm{N}^{\prime}$-terminus catalyses AMPylation. Then, SidM catalyses the exchange of GDP for GTP by changing the conformation of Rab1 residues that are important for nucleotide stabilization (Murata et al., 2006). AMPylation induces cell rounding and shrinkage, which contribute to the disruption of cell homeostasis and to cytotoxicity (Muller et al., 2010). SidM is localized to the membrane through its interaction with PI4P (see above), and recruits Rab1/GTP to the Legionella-containing vesicles, mimicking a Rab1/GEF and delaying GAP activity by AMPylation. SidM-mediated Rab1 activation and recruitment to the Legionella-containing vesicles promotes fusion of ER-derived vesicle with the Legionella-containing vesicles. Another L. pneumophila effector is LepB, that functions as a GAP for Rab1 (Ingmundson et al., 2007), inactivating the GTPase and releasing it from the Legionella-containing vesicles, promoting ist fusion with the ER. During the initial phase of infection, L. pneumophila resides in the ER-derived vesicle that interacts with the secretory pathway, whereas during the later stages of infection, when bacterial replication occurs, these vesicles acquire lysosomal markers (Sturgill-Koszycki \& Swanson, 2000).

\subsection{A unique infection model: Mycobacterium tuberculosis}

The infection of a macrophage by $M$. tuberculosis is complex, and since a variety of pathways are orchestrated by the pathogen, a separated section is dedicated to analyze this pathogen.

M. tuberculosis is able to survive, reside, and multiply in macrophages as an intracellular parasite, circumventing all defence pathways of the host. The hallmarks of Mycobacterium infection are (a) the manipulation of phagolysosome maturation (Koul et al., 2004; Hestvik et al., 2005), (b) the prevention of antigen presentation (Moreno et al., 1988), (c) a decrease in stimulators of apoptosis (Balcewicz-Sablinska et al., 1998), (d) alteration of IFN- $\gamma$ activity (Sibley et al., 1988), and (e) modulation of MAPK and JAK/STAT signalling pathways (Koul et al., 2004). 
Upon internalization by macrophage phagocytosis, $M$. tuberculosis is able to arrest phagolysosome fusion (Pethe et al., 2004) and modulate other macrophage defences to promote its survival (Gan et al., 2008). Arrested M. tuberculosis-containing phagosomes are characterized by the presence of Rab5a, but the recruitment of its effectors, such as EEA1 and hVPS34, is impaired (Fratti et al., 2001). M. tuberculosis uses a range of protein and lipid effectors to alter the PI(3)P signalling (Vergne et al., 2005) and the concentration of cytosolic $\mathrm{Ca}^{2+}$, both events essential for the proper phagosomal maturation (Jaconi et al., 1990). The mycobacterial mannosylated lipoarabinomanan (Man-LAM), a shed component of the cell wall, is distributed throughout the endocytic network (Beatty et al., 2000), preventing the increase in cytosolic $\left[\mathrm{Ca}^{2+}\right]$, a process necessary for phagocytosis upon activation of hVPS34 by calmodulin (Vergne et al., 2003). Inhibition of the PI3K pathway by Man-LAM also blocks the delivery of lysosomal proteins, such as hydrolases (e.g. cathepsin D) and the membrane-docking fusion protein syntaxin 6, from the trans-Golgi network to phagosomes (Fratti et al., 2003). In addition, the pathogen further impairs cytosolic $\mathrm{Ca}^{2+}$ flux by inhibiting sphingosine kinase, which converts sphingosine to sphingosine-1-phosphate, which in turn promotes $\mathrm{Ca}^{2+}$ efflux from the endoplasmic reticulum (Malik et al., 2003). M. tuberculosis also produces the phosphatase SapM, which has been shown to specifically inhibit hydrolysis of $\mathrm{PI}(3) \mathrm{P}$ in vitro (Vergne et al., 2005). These findings indicate that Man-LAM blocks phagosome maturation by inhibiting a signalling cascade based on [ $\left.\mathrm{Ca}^{2+}\right]$, calmodulin, and PI3K. Mycobacterial phagosomes also recruit early phagosomal proteins such as coronin-1 (Ferrari et al., 1999), but avoid acidification as the bacteria specifically exclude the vesicular proton ATPase from the phagosomal membrane (Sturgill-Koezycki et al., 1994, Wong et al., 2011).

Macrophages infected with harmful bacteria activate their own apoptotic program when the infected cell cannot resolve its infection. However, many bacterial pathogens alter host apoptotic pathways (Spira et al., 2003). Mycobacteria-induced macrophage apoptosis is a complex mechanism that is modulated by mycobacterial virulence factors (Nigou et al., 2002). $\mathrm{Ca}^{2+}$ is thought to facilitate apoptosis by increasing the permeability of mitochondrial membranes, and then promoting the release of pro-apoptotic factors such as cytochrome $c$ (Szalai et al., 1999). Interestingly, Man-LAM also stimulates the phosphorylation of the apoptotic protein Bad, preventing it from binding to the anti-apoptotic proteins Bcl-2 and Bcl-XL (Maiti et al., 2001).

Pro-inflammatory cytokines, such as IL-1, IL-6, TNF- $a$, and IFNs, are able to induce a cellular innate immune response when macrophages sense invading bacteria.

The activation of MAPK signalling in macrophages that are infected with non-pathogenic mycobacteria leads to the synthesis of various microbicidal molecules, including TNF- $\alpha$, which mediate antibacterial and inflammatory immune responses (Roach \& Schorey, 2002). These observations are supported by a study that demonstrated that the secretion of TNF- $\alpha$ by macrophages infected with $M$. avium is dependent on MEK1 and ERK1 and 2 activation (Reiling et al., 2001). A high level of TNF- $\alpha$ is a crucial factor for controlling primary infection, as it induces the expression of other pro-inflammatory cytokines, such as IL-1, and of several chemotactic cytokines, which attract immune cells to the site of infection.

Tyrosine phosphorylation of JAK and STAT has been shown to be essential for the antibacterial response of macrophages (Decker et al., 2002). Pathogenic mycobacteria have 
evolved mechanisms to suppress the IFN-ץ and JAK/STAT signalling pathways (Hussain et al., 1999) by mechanisms not yet elucidated.

Surprisingly, two protein tyrosine phosphatases PtpA and PtpB are annotated in the genome sequence of $M$. tuberculosis (Cole et al., 1998). The presence of such proteins is interesting, since their partners, protein tyrosine kinases, are not predicted from the genome sequence, which suggests they play a role in the survival of the pathogen in host macrophages. The role of PtpA has been elucidated (Bach et al., 2008). This phosphatase is secreted within human macrophages upon infection and translocates into the cytosol to dephosphorylate VPS33B, an ubiquitously expressed protein essential for vesicle trafficking. Then, by dephosphorylating VPS33B, the pathogen prevents the maturation of the phagosome. Interestingly, a study reported the first protein tyrosine kinase, PtkA, in $M$. tuberculosis (Bach et al., 2009). This tyrosine kinase phosphorylates PtpA- although the role of this activity remains to be elucidated. The second protein tyrosine phosphatase annotated in the M. tuberculosis genome is PtpB. Interestingly, PtpB orthologs are restricted to pathogenic Mycobacteria. It has been reported that PtpB blocks the ERK1 and 2 pathways in murine macrophages, but its mechanism has not yet been elucidated (Zhou et al., 2010).

Another virulence protein secreted by M. tuberculosis is the protein kinase G. Although this protein has been shown to participate in the inhibition of phagolysosome fusion in M. bovis strain BCG (Walburger et al., 2004), its mechanism has not yet been elucidated.

\section{Conclusion}

In this chapter, the mechanisms through which virulence proteins and conserved microbial structures can initiate macrophage signalling were discussed. Macrophages can use specific receptors and common signalling pathways to integrate this information to mount an immunological response, but they are still vulnerable to subversion by bacterial pathogens that can interfere with crucial kinase, trafficking or transcriptional networks. However, there are redundancies in macrophage signalling pathways, and the recent discovery of a cytosolic detection system in macrophages is a good example of how avoiding one component of a macrophage's arsenal makes pathogens vulnerable to another. It seems that the combination of mechanisms that a pathogen has to modify specific macrophage signalling cascades dictates their most successful niche.

Genome sequencing projects have identified an overwhelming number of host and bacterial genes that encode proteins with unknown functions. The characterization of the biological functions of these proteins will probably add to the ever-increasing number and diversity of strategies that are used by macrophages to detect and contain the invaders and by bacterial pathogens to subvert and evade host responses.

Finally, the development of new technologies, such as improvements in mass spectrometry techniques, will undoubtedly increase the currently known post-translational modification and facilitate the understanding of their roles in host-pathogen interactions. Identifying pathogen-encoded enzymes that catalyze specific post-translational modification critical for infection will provide valuable new targets for drug development. Indeed, the selective inhibition of these enzymes may constitute a promising strategy to contain and restrict the proliferation of pathogens. However, only few interaction partners have been identified so far. Systematic mapping of protein-protein interactions can provide valuable insights into 
biological systems. However, current large-scale screening methods fail to provide information about these interactions.

\section{Acknowledgment}

The author thanks Jeffrey Helm and Eviatar Bach for helpful discussions and technical support.

\section{References}

Akira, S. \& Takeda, K. (2004). Toll-like receptor signalling. Nature Reviews Immunology, Vol.4, No.7, (July 2004), pp. 499-511

Alto, N.; Shao, F.; Lazar, C.; Brost, R.; Chua, G.; Mattoo, S.; McMahon, S.; Ghosh, P.; Hughes, T.; Boone, C. \& Dixon, J. (2006). Identification of a bacterial type III effector family with G protein mimicry funcions. Cell, Vol.124, No.1, (January 2006), pp. 133-145

Arbibe, L.; Kim, D.; Batsche, E.; Pedron, T.; Mateescu, B.; Muchardt, C.; Parsot, C. \& Sansonetti, P. (2007). An injected bacterial effector targets chromatin access for transcription factor NF-kappaB to alter transcription of host genes involved in immune responses. Nature Immunology, Vol.8, No.1, (January 2007), pp. 47-56

Asim, M.; Chaturvedi, R.; Hoge, S.; Lewis, N.; Singh, K.; Barry, D.; Algood, H.; de Sablet, T.; Gobert, A. \& Wilson, K. (2010). Helicobacter pylori induces ERK-dependent formation of a phospho-c-Fos.c-Jun activator protein-1 complex that causes apoptosis in macrophages. Journal of Biological Chemistry, Vol.285, No.26, (June 2010), pp. 20343-20357

Bach, H.; Papavinasasundaram, K.; Wong, D.; Hmama, Z. \& Av-Gay, Y. (2008). Mycobacterium tuberculosis virulence is mediated by PtpA dephosphorylation of human vacuolar protein sorting 33B. Cell Host Microbe, Vol.15, No.3, (May 2008), pp. 316-322

Bach, H.; Wong, D. \& Av-Gay, Y. (2009). Mycobacterium tuberculosis PtkA is a novel protein tyrosine kinase whose substrate is PtpA. Biochemical Journal, Vol.420, No.2, (May 2009), pp. 155-160

Balcewicz-Sablinska, M.; Keane, J.; Kornfeld, H. \& Remold, H. (1998). Pathogenic Mycobacterium tuberculosis evades apoptosis of host macrophages by release of TNF-R2, resulting in inactivation of TNF-alpha. Journal of Immunology, Vol.161, No. 5, (September 1998), pp. 2636-2641

Bakowsky, M.; Braun, V.; Lam, G.; Yeung, T.; Heo, W.; Meyer, T.; Finlay, B.; Grinstein, S. \& Brumell, J. (2010). The phosphoinositide phosphatase SopB manipulates membrane surface charge and trafficking of the Salmonella-containing vacuole. Cell Host Microbe, Vol.7, No.6, (June 2010), pp. 453-462

Bhattacharyya, A.; Pathak, S.; Datta, S.; Chattopadhyay, S.; Basu, J. \& Kundu, M. (2002). Mitogen-activated protein kinases and nuclear factor-kappaB regulate Helicobacter pylori-mediated interleukin-8 release from macrophages. Biochemical Journal, Vol.368, No.1, (November 2002), pp. 121-129 
Beatty, W.; Rhoades, E.; Ullrich, H.; Chatterjee, D.; Heuser, J. \& Russell, D. (2000). Trafficking and release of mycobacterial lipids from infected macrophages. Traffic, Vol.1, No.3, (March 2000), pp. 235-247

Black, D. \& Bliska, J. (1997). Identification of p130Cas as a substrate of Yersinia YopH (Yop51), a bacterial protein tyrosine phosphatase that translocates into mammalian cells and targets focal adhesions. EMBO Journal, Vol.16, No.10, (May 1997), pp. 2730-2744

Boehm, U.; Klamp, T.; Groot, M. \& Howard, J. (1997).Cellular response to interferon-gamma. Annual Review of Immunology, Vol. 15, pp. 749-795

Brombacher, E.; Urwyler, S.; Ragaz, C.; Weber, S.; Kami, K.; Overduin, M. \& Hilbi, H. (Rab1 guanine nucleotide exchange factor SidM is a major phosphatidylinositol 4phosphate-binding effector protein of Legionella pneumophila. Journal of Biological Chemistry, Vol. 284, No.8, (February 2009), pp. 4846-4856

Bromman, P.; Korkaya, S. \& Courtneidge, S. (2004). The interplay between Src family kinases and receptor tyrosine kinases. Oncogenes, Vol.23, No.48 (October 2004), pp. 7957-7968

Cascales, E. \& Christie, P. (2003). The versatile bacterial type IV secretion systems. Nature Review Microbiology, Vol.1, No.2, (November 2003), pp. 137-149

Celi, J.; Olivier, M. \& Finlay, F. (2001). Enteropathogenic Escherichia coli mediates antiphagocytosis through the inhibition of PI 3-kinase-dependent pathways. EMBO Journal, Vol.20, No.6, (March 2001), pp. 1245-1258

Chamaillard, M.; Hashimoto, M.; Horie, Y.; Masumoto, J.; Qui, S.; Saab, L., Ogura, Y.; Kawasaki, A.; Fukase, K.; Kusumoto, S.; Valvano, M.; Foster, S.; Mak, T,; Nunez, G \& Inohara, N. An essential role for NOD1 in host recognition of bacterial peptidoglycan containing diaminopimelic acid. Nature Immunology, Vol.4, No.7, (July 2003), pp. 702-707

Charras, G. \& Paluch, E. (2008). Blebs lead the way: how to migrate without lamellipodia. Nature Review Molecular Cell Biology, Vol.9, No.9, (September 2008), pp. 730-736

Cole, S.; Brosch, R.; Parkhill, J.; Garnier, T.; Churcher, C.; Harris D., et al. (1998). Deciphering the biology of Mycobacterium tuberculosis from the complete genome sequence. Nature, Vol.393, No.6685, (June 1998), pp. 537-544

Cox, D.; Lee, D.; Dale, B.; Calafat, J. \& Greenberg, S. (2000). A Rab11-containing rapidly recycling compartment in macrophages that promotes phagocytosis. Proceedings of the National Academy of Science United States of America, Vol.97, No.2, (January 2000), pp. 680-685

Decker, T.; Stockinger, S.; Karaghiosoff, M.; Muller, M. \& Kovarik P. (2002). IFNs and STATs in innate immunity to microorganisms. Journal of Clinical Investigation, Vol.109, No.10, (May 2002), pp. 1271-1277

Desjardins, M.; Huber, L.; Parton, R. \& Griffiths, G. (1994). Biogenesis of phagolysosomes proceeds through a sequential series of interactions with the endocytic apparatus. Journal of Cell Biology, Vol.124, No.5, (March 1994), pp. 677-688

Di Paolo, G. \& De Camilli, P. (2006). Phosphoinositides in cell regulation and membrane dynamics. Nature, Vol.443, No.7112, (October 2006), pp. 651-657 
Ferrari, G.; Langen, H.; Naito, M. \& Pieters, J. (1999). A coat protein on phagosomes is involved in the intracellular survival of mycobaceria. Cell, Vol.97, No.4, (May 1999), pp. $435-447$

Fitzgerald, K.; Palsson-McDermott, E.; Bowie, A.; Jefferies C.; Mansell, A.; Brady, G. et al., (2001). Mal (MyD88-adapter-like) is required for Toll-like receptor-4 signal transduction. Nature, Vol.413, N0.6851, (September 2001), pp. 78-83

Fitzgerald, K.; Rowe, D.; Barnes, B.; Caffrey, D.; Visintin, A.; Latz, E. et al. (2003). LPS-TLR4 signalling to IRF-3/7 and NF-kappaB involves the toll adapters TRAM and TRIF. Journal of Experimental Medicine, Vol.198, No.7, (October 2003), pp. 1043-1055

Fratti, R.; Becker, J.; Gruenberg, J.; Corvere, S. \& Deretic, V. (2001). Role of phosphatidylinositol 3-kinase and Rab5 effectors in phagosomel biogenesis and mycobacterial phagosome maturation arrest. Journal of Cell Biology, Vol.154, No.3, (August 2001), pp. 631-644

$\mathrm{Fu}$, Y. \& Galan, J. (1998). The Salmonella typhimurium tyrosine phosphatase SptP is translocated into host cells and disrupts the actin cytoskeleton. Molecular Microbiology, Vol.27, No.2, (January 1998), pp. 359-368

Fu, Y. \& Galan, J. (1999). A Salmonella protein antagonizes Rac-1 and Cdc42 to mediate hostcell recovery after bacterial invasion. Nature, Vol.401, No.6750, (September 1999), pp. 293-297

Galan, J. \& Wolf-Watz, H. (2006). Protein delivery into eukaryotic cells by type III secretion machines. Nature, Vol.444, No.7119, (November 2006), pp. 567-573

Gan, H.; Lee, J.; Ren, F.; Chen, M.; Kornfeld, H. \& Remold, H. (2008). Mycobacterium tuberculosis blocks crosslinking of annexin-1 and apoptotic envelope formation on infected macrophages to maintain virulence. Nature Immunology, Vol.9, No.10, (October 2008), pp. 1189-1197

Gao, X.; Wan, F.; Mateo, K.; Callegari, E.; Wang, D.; Deng, W.; Punte, J.; Li, F.; Chaussee, M.; Finlay, B.; Lenardo, M. \& Hardwidge, P. (2009). Bacterial effector binding to ribosomal protein s3 subverts NF-kappaB function. PLoS Pathogens, Vol.5, No.12, (December 2009), pp. e1000708

Gay, N. \& Gangloff, M. (2007). Structure and function of toll receptors and their ligands. Annual Review of Biochemistry, Vol.76, pp. 23.1-23.25

Ghosh, P. (2004). Process of protein transport by the type III secretion system. Microbiology and Molecular Biology Reviews, Vol.68, No.4, (December 2004), pp. 771-795

Girardin, S.; Boneca, I.; Viala, J.; Chamaillard, M.; Labigne, A.; Thomas, G.; Philpott, D. \& Sansonetti, P. (2003). Nod2 is a general sensor of peptidoglycan through muramyl dipeptide (MDP) detection. Journal of Biological Chemistry, Vol.278, No.11, (March 2003), pp. 8869-8872

Gouin, E.; Adib-Conquy, M.; Balestrino, D.; Nahori, M.; Villiers, V.; Colland, F.; Dramsi, S.; Dussurget, O. \& Cossart, P. (2010). The Listeria monocytogenes InIC protein interferes with innate immune responses by targeting the IkappaB kinase subunit IKKalpha. Proceedings of the National Academy of Science United States of America, Vol.107, No.40, (October 2010), pp. 17333-17338 
Grosdent, N.; maridonneau-Parini, I.; Sory, M. \& Cornelis, G. (2002). Role of Yops and adhesins in resistance of yersinia enterolitica to phagocytosis. Infection \& Immunity, Vol.70, No.8, (August 2002), pp. 4165-4176

Haas, A. (2007). The phagosome: compartment with a license to kill. Traffic, Vol.8, No.4, (April 2007), pp. 311-330

Hakansson, S.; Galyov, E.; Rosqvist, R. \& Wolf-Watz, H. (1996). The Yersinia YpkA Ser/Thr kinase is translocated and subsequently targeted to the inner surface of the HeLa cell plasma membrane. Molecular Microbiology, Vol.20, No.3, (May 1996), pp. 593603

Handa, Y.; Suzuki, M.; Ohya, K.; Iwai, H.; Ishujima, N.; Koleske,A.; Fukui, Y. \& Sasakawa, C. (2007). Shigella IpgB1 promotes bacterial entry through the ELMO-Dock180 machinery. Nature Cell Biology, Vol.9, No.1, (January 2007), pp. 121-128

Hardt, W.; Chen, L.; Schuebel, K.; Bustelo, X. \& Alan, J. (1998). S. typhimurium encodes an activator of Rho GTPases that induces membrane ruffling and nuclear responses in host cells. Cell, Vol.93, No5., (May 1998), pp. 815-826

Hernandez, L.; Hueffer, K.; Wenk, M. \& Galan, J. (2004). Salmonella modulates vesicular traffic by altering phosphoinositide metabolism. Science, Vol.304, No.5678, (June 2004), pp. 1805-1807.

Hestvik, A.; Hmama, Z. \& Av-Gay Y. (2005). Mycobacterial manipulation of the host cell. FEMS Microbiology Reviews, Vol.29, No.5, (November 2005), pp. 1041-1050

Honda, K. \& Taniguchi, T. (2006). IRFs: master regulators of signalling by Toll-receptors and cytosolic pattern-recognition receptors. Nature Reviews Immunology, Vol.6, No.9, (September 2006), pp. 644-658

Hussain, S.; Zwilling, B. \& Lafuse, W. (1999). Mycobacterium avium infection of mouse macrophages inhibits IFN-gamma Janus kinase-STAT signalling and gene induction by downregulation of the IFN-gamma receptor. Journal of Immunology, Vol.163, No.4, (August 1999), pp. 2041-2048

Ingmundson, A.; Delprato, A.; Lambright, D. \& Roy, C. (2007). Legionella pneumophila proteins that regulate Rab1 membrane cycling. Nature, Vol.450, No.7168, (November 2007), pp. 365-369

Inohara, N. \& Nunez, G. (2003). NODs: intracellular proetins involved in inflammation and apoptosis. Nature Reviews Immunology, Vol.3, No.5, (May 2003), pp. 371-382

Ishii, K.; Koyama, S.; Nakagawa, A.; Coban, C. \& Akira, S. (2008). Host innate immune receptors and beyond: making sense of microbial infections. Cell Host Microbe, Vol.3, No.8, (June 2008), pp. 352-363

Iwasaki, A. \& Medzhitov, R. (2004). Toll-like receptor control of the adaptive immune responses. Nature Immunology, Vol.5, No.10, (October 2004), pp. 987-995

Jaconi, M.; Lew, D.; Carpentier, J.; Magnusson, K.; Sjogren, M. \& Stendahl, O. (1990) Cytosolic free calcium elevation mediates the phagosome-lysosome fusion during phagocytosis in human neutrophils. Journal of Cell Biology, Vol.110, No.5, (May 1990), pp. 1555-1564

Jahraus, A.; Storrie, B.; Griffiths, G. \& Desjardins, M. (1994). Evidence for retrograde traffic between terminal lysosomes and the prelysosomal/late endosome compartment. Journal of Cell Biology, Vol.107, No.1, (January 1994), pp. 145-157 
Johnson, G. \& Lapadat, R. (2002). Mitogen-activated protein kinase pathways mediated by ERK, JNK, and p38 protein kinases. Science, Vol.298, No.5600, (December 2002), pp. 1911-1912

Kagan, J. \& Roy, C. (2002). Legionella phagosomes intercept vesicular traffic from endoplasmic reticulum exit sites. Nature Cell Biology, Vol.4, No.12, (December 2002), pp. 945-954

Kawagoe, T.; Sato, S.; Matsushita, K.; Kato, H.; Matsui, K.; Kumagai, Y. et al. (2008). Sequential control of toll-like receptor-dependent responses by IRAK1 and IRAK2. Nature Immunology, Vol.9, No.6, (June 2008), pp. 684-691

Kayal, S.; Lilienbaum, A.; Join-Lambert, O.; Li, X.; Israel, A. \& Berche, P. (2002). Listeriolysin O secreted by Listeria monocytogenes induces NF-kappaB signalling by activating the IkappaB kinase complex. Molecular Microbiology, Vol. 44, No.5, (June 2002), pp. 1407-1419

Klink, B.; Barden, S.; Heidler, T.; Borchers, C.; Ladwein, M.; Stradal, T.; Rottner, K. \& Heinz, D. (2010). Structure of Shigella IpgB2 in complex with human RhoA: implications for the mechanism of bacterial guanine nucleotide exchange factor mimicry. Journal of Biological Chemistry, Vol.285, No.22, (May 2010), pp. 17197-17208

Kobayashi, K.; Hernandez, L.; Galan, J.; Janeway, C.; Medzhitov, R. \& Flavelli, R. (2002). IRAK-M is a negative regulator of Toll-like receptors signalling. Cell, Vol.110, No.2, (July 2002), pp. 191-202

Koul, A.; Herget, T.; Klebl, B. \& Ullrich, A. (2004). Interplay between mycobacteria and host signalling pathways. Nature Reviews Microbiology, Vol.2, No.3 (March 2004), pp. 189-202

Kubori, T. \& Galan, J. (2003). Temporal regulation of Salmonella virulence effector function by proteosome-dependent protein degradation. Cell, Vol.115, No.3, (October 2003), pp. 333-342

Li, H.; Xu, H.; Zhou, Y.; Zhang, J.; Lomg, C.; Li, S.; Chen, S.; Zhou, J. \& Shao, F. (2007). The phosphothreonine lyase activity of a bacterial type III effector family. Science, Vol.315, No.5814, (February 2007), pp. 1000-1003

Lin, S.; Le, T. \& Cowen, D. (2003). SptP, a Salmonella typhimurium type III-secreted protein, inhibits the mitogen-activated protein kinase pathway by inhibiting Raf activation. Cellular Microbiology, Vol.5, No.4, (April 2003), pp. 267-275

Maiti, D.; Bhattacharyya, A. \& Basu, J. (2001). Lipoarabinomannan from Mycobacterium tuberculosis promotes macrophage survival by phosphorylating Bad through a phosphatidylinositol 3-kinase/Akt pathway. Journal of Biological Chemistry, Vol.276, No.1, (January 2001), pp. 329-333

Malik, Z.; Thompson, C.; Hashimi, S.; Porter, B.; Iyer, S. \& Kusner, D. (2003). Cutting edge: Mycobacterium tuberculosis blocks $\mathrm{Ca}^{2+}$ signalling and phagosome maturation in human macrophages via specific inhibition of sphingosine kinase. Journal of Immunology, Vol.170, No.6, (March 2003), pp. 2811-2815

Mallo, G.; Espina, M.; Smith, A.; Terebiznik, M.; Aleman, A.; Finlay, B.; Rameh, L.; Grinstein, S. \& Brummel, J. (2008). SopB promotes phosphatidylinositol 3-phosphate formation on Salmonella vacuoles by recruiting Rab5 and Vps34. Journal of Cell Biology, Vol.182, No.4, (August 2008), pp. 741-752 
Mason, D.; mallo, G.; Terebiznik, M.; Payrastre, B.; Finlay, B.; Brumell, J.; Rameh, L. \& Grinstein, S. (2007). Alteration of epithelial structure and function associated with PtdIns $(4,5) \mathrm{P} 2$ degradation by a bacterial phosphatase. Journal of General Physiology, Vol.129, No.4, (April 2007), pp. 267-283

Mazurkiewicz, P.; Thomas, J.; Thompson, J.; Liu, M.; Arbibe, L.; Sansonetti, P. \& Holden, D. (2008). SpvC is a Salmonella effector with phosphothreonine lyase activity on host mitogen-activated protein kinases. Molecular Microbiology, Vol.67, No.6, (March 2008), pp. 1371-1383

Medzhitov, R. (2008). Origin and physiological roles of inflammation. Nature, Vol.454, No.7203, (July 2008), pp. 428-435

Mittal, R.; Peak-Chew, S. \& McMahon, H. (2006). Acetylation of MEK2 and I kappa B kinase (IKK) activation loop residues by YopJ inhibits signalling. Proceedings of the National Academy of Science United States of America, Vol.103, No.49, (October 2010), pp. 18574-18579

Moreno, C.; Mehlert, A. \& Lamb, J. (1988). The inhibitory effects of mycobacterial lipoarabinomannan and polysaccharides upon polyclonal and monoclonal human T cell proliferation. Clinical and Experimental Immunology, Vol.74, No.2, (November 1988), pp. 206-210

Mostowy, S. \& Cossart, P. (2009). Cytoskeleton rearrangements during Listeria infection: clathrin and septins as new players in the game. Cell Motility and the Cytoskeleton, Vol.66, No.10, (October 2009), pp. 816-823

Mukherjee, S.; Keitany, G.; Li, Y.; Wang, Y.; Ball, H.; Goldsmith, E. \& Orth, K. (2006). Yersinia YopJ acetylates and inhibits kinase activation by blocking phosphorylation. Science, Vol.312, No.5777, (May 2006), pp. 1211-1214

Muller, M.; Peters, H.; Blumer, J.; Blankenfeldt, W.; Goody, R. \& Itzen, A. The Legionella effector protein DrrA AMPylates the membrane traffic regulator Rab1b. Science, Vol.329, No.5994, (August 2010), pp. 946-949

Murata, T.; Delprato, A.; Ingmundson, A.; Toomre, D.; Lambright, D. \& Roy, C. (2006). The Legionella pneumophila effector protein DrrA is a Rab1 guanine-nucleotide-exchange factor. Nature Cell Biology, Vol.8, No.9, (September 2006), pp. 971-979

Niebuhr, K.; Jouihri, N.; Allaoui, A.; Gounon, P.; Sansonetti, P. \& Parsot, C. (2000). IpgD, a protein secreted by the type III secretion machinery of Shigella flexneri, is chaperoned by IpgE and implicated in entry focus formation. Molecular Microbiology, Vol.38, No.1, (October 2000), pp. 8-19

Niebuhr, K.; Giuriato, S.; Pedron, T.; Philpott, D.; Gaits, F.; Sable, J.; Sheetz, M.; Parsot, C.; Sansonetti, P. \&Payrastre, B. (2002). Conversion of PtdIns(4,5)P(2) into PtdIns(5)P by the $S$. flexneri effector IpgD reorganizes host cell morphology. EMBO Journal, Vol.21, No.19, (October 2002), pp. 5069-5078

Nigou, J.; Guilleron, M.; Rojas, M.; Garcia, L.; Thurnher, M. \& Puzo, G. (2002). Mycobacterial lipoarabinomannans: modulators of dendritic cell function and the apoptotic response. Microbes and Infection, Vol.4, No.9, (July 2003), pp. 945-953

O'Neill, L. \& Bowie, A. (2007). The family of five: TIR-domain containing adaptors in Tolllike receptor signalling. Nature Reviews Immunology, Vol.7, No.5, (May 2007), pp. 353-364 
Orth, K.; Palmer, L.; Bao, Z.; Stewart, S.; Rudolph, A.; Bliska, J. \& Dixon, J. (1999). Inhibition of the mitogen-activated protein kinase kinase superfamily by a Yersinia effector. Science, Vol.285, No.5435, (September 1999), pp. 1920-1923

Orth, K.; Xu, Z.; Mudgett, M.; Bao, Z.; Palmer, L.; Bliska, J.; Mangel, W.; Staskawicz, B. \& Dixon, J. (2000). Disruption of signalling by Yersinia effector YopJ, a ubiquitin-like protein protease. Science, Vol.290, No.5496, (November 2000), pp. 1594-1597

Park, J.; Greten, F.; Li, Z. \& Karin, M. (2002). Macrophage apoptosis by anthrax lethal factor through p38 MAP kinase inhibition. Science, Vol.297, No.5589, (September 2002), pp. 2048-2051

Patel, J. \& Galan, J. (2005). Manipulation of the host actin cytoskeleton by Salmonella-all in the name of entry. Current Opinion in Microbiology, Vol.8, No.1, (February 2005), pp. 10-15

Pehleven, A.; Wrighy, D.; Andrews, C.; George, K.; Small, P. \& Foxwell, B. (1999). The inhibitory action of Mycobacterium ulcerans soluble factor on monocyte/T cell cytokine production and NF-kappa B function. Journal of Immunology, Vol.163, No.7, (October 1999), pp. 3928-3935

Pethe, K.; Swenson, D.; Alonso, S.; Anderson, J.; Wang, C. \& Russell, D. (2004). Isolation of Mycobacterium tuberculosis mutants defective in the arrest of phagosome maturation. Proceedings of the National Academy of Science United States of America, Vol.101, No.37, (September 2004), pp. 13642-13647

Ragaz, C.; Pietsch, H.; Urwyler, S.; Tiaden, A.; Weber, S. \& Hilbi, H. (2008). The Legionella pneumophila phosphatidylinositol-4 phosphate-binding type IV substrate SidC recruits endoplasmic reticulum vesicles to a replication-permissive vacuole. Cellular Microbiology, Vol.10, No.12, (December 2008), pp. 2416-2433.

Reiling, N.; Blumenthal, A.; Flad, H.; Ernst, M. \& Ehlers, S. (2001). Mycobacteria-induced TNF-alpha and IL-10 formation by human macrophages is differentially regulated at the level of mitogen-activated protein kinase activity. Journal of Immunology, Vol.167, No.6, (September 2001), pp. 3339-3345

Roach, S. \& Schorey, J. (2002). Differential regulation of the mitogen-activated protein kinases by pathogenic and nonpathogenic mycobacteria. Infection \& Immunity, Vol.70, No.6, (June 2002), pp. 3040-3052

Rusten E. \& Stenmark, H. (2006). Analyzing phosphoinositides and their interacting proteins. Nature Methods, Vol.3, No.4, (April 2006), pp. 251-258

Sato, S.; Sanjo, H.; Takeda, K.; Ninomiya-Tsuji, J.; Yamamoto, M.; Kawai, T. et al. (2005). Essential function for the kinase TAK1 in innate and adaptive immune response. Nature Immunology, Vol.6, No.11, (November 2005), pp. 1087-1095

Schesser, K.; Spiik, A.; Dukuzumuremyi, J.; Neurath, M.; Petterson, S. \& Wolf-Watz, H. (1998). The yopJ locus is required for Yersinia-mediated inhibition of NF-kappaB activation and cytokine expression: YopJ contains a eukaryotic SH2-like domain that is essential for its repressive activity. Molecular Microbiology, Vol.28, No.6, (June 1998), pp. 1067-1079

Seveau, S.; Bierne, H.; Giroux, S.; Prevost, M. \& Cossart, P. (2004). Role of lipid rafts in Ecadherin- and HGF-R/Met-mediated entry of Listeria monocytogenes into host cells. Journal of Cell Biology, Vol.166, No.5, (August 2004), pp. 743-753 
Shao, F.; Merritt, P.; Bao, Z.; Innes, R. \& Dixon, J. (2002). A Yersinia effector and a Pseudomonas avirulence protein define a family of cysteine proteses functioning in bacterial pathogenesis. Cell, Vol.109, No.5, (May 2002), pp. 575-588

Shen, Y.; Naujokas, M.; Park, M. \& Ireton, K. (2000). InlB-dependent internalization of Listeria is mediated by the Met receptor tyrosine kinase. Cell, Vol.103, No.3, (October 2000), pp. 501-510

Shtrichman, R.; \& Samuel, C. (2001). The role of gamma interferon in antimicrobial immunity. Current Opinion in Microbiology, Vol. 4, No.3, (June 2001), pp. 251-259

Sibley, L.; Hunter, S.; Brennan, P. \& Krahenbuhl, J. (1988). Mycobacterial lipoarabinomannan inhibits gamma interferon-mediated activation of macrophages. Infection \& Immunity, Vol.56, No.5, (May 1988), pp. 1232-1236

Spira, A.; Carroll, J.; Liu, G.; Aziz, Z.; Shah, V.; Kornfeld, H. \& Keane, J. (2003). Apoptosis genes in human alveolar macrophages infected with virulent or attenuated $M$. tuberculosis. American Journal of Respiratory Cell Molecular Biology, Vol.29, No.5, (November 2003), pp. 545-551

Sprang, S. (1997). G protein mechanisms: Insights from structural analysis. Annual Reviews Biochemistry, Vol.66, pp. 639-678

Steele-Mortimer, O.; Meresse, S.; Gorvel, J.; Toh, B. \& Finlay, B. (1999). Biogenesis of Salmonella typhimurium-containing vacuoles in epithelial cells involves interactions with the early endocytic pathway. Cellular Microbiology, Vol.1, No.1, (July 1999), pp. 33-49

Sturgill-Koszycki, S.; Schlesinger, P.; Chakraborty, P.; Haddix, P.; Collins, H.; Fok, A.; Allen, R.; Gluck, S.; Heuser, J. \& Russell, D. (1994). Lack of acidification in Mycobacterium phagosomes produced by exclusion of the vesicular proton-ATPase. Science, Vol.263, No.5147, (February 1994), pp. 678-681

Sturgill-Koszycki, S. \& Swanson, M. (2000). Legionella pneumophila replication vacuoles mature into acidic, endocytic organelles. Journal of Experimental Medicine, Vol.192, No.9, (November 2000), pp. 1261-1272

Szalai, G.; Krishnamurthy, R. \& Hajnoczky, G. (1999). Apoptosis driven by $\mathrm{IP}_{3}$-linked mytochondrial calcium signals. EMBO Journal, Vol.18, No.22, (November 1999), pp. 6349-6361

Takeuchi, O. \& Akira, S. (2010). Pattern recognition receptors and inflammation. Cell, Vol.140, No.6, (March 2010), pp. 805-820

Ting, L.; Kim, A.; Cattamanchi, A. \& Ernst, J. (1999). Mycobacterium tuberculosis unhibits IFNgamma transcriptional responses without inhibiting activation of STAT1. Journal of Immunology, Vol.163, No.7, (October 1999), pp. 3898-3906

Turk, B. (2007). Manipulation of host signalling pathways by anthrax toxins. Biochemical Journal, Vol.402, No.3, (March 2007), pp. 405-417

Velledor, A.; Comalada, M.; Xaus, J. \& Celada, A. (2000). The differential time-course of extracellular-regulated kinase activity correlates with the macrophage response toward proliferation or activation. Journal of Biological Chemistry, Vol.275, No.10, (March 2010), pp. 7403-7409 
Vergne, I.; Chua, J. \& Deretic, V. (2003). Tuberculosis toxin blocking phagosome maturation inhibits a novel $\mathrm{Ca}^{2+} /$ calmodulin-PI3K hVPS34 cascade. Journal of Experimental Medicine, Vol.198, No.4, (August 2003), pp. 653-659

Vergne, I.; Chua, J.; Lee H.; Lucas, M.; Belisle, J. \& Deretic, V. (2005). Mechanism of phagolysosome biogenesis block by viable Mycobacterium tuberculosis. Proceedings of the National Academy of Science United States of America, Vol.102, No.11, (March 2005), pp. 4033-4038

Viboud, G. \& Bliska, J. (2001). A bacterial type III secretion system inhibits actin polymerization to prevent pore formation in host cell membranes. EMBO Journal, Vol.20, No.19, (October 2001), pp. 5373-5382

Von Pawel-Rammingen, U.; Telepnev, M.; Schmidt, G.; Aktories, K.; Wolf-Watz, H. \& Rosqvist, R. (2000). GAP activity of the Yersinia YopE cytotoxin specifically targets the Rho pathway: a mechanism for disruption of actin microfilament structure. Molecular Microbiology, Vol.36, No.3, (May 2000), pp. 737-748

Walburger, A.; Koul, A.; Ferrari, G.; Nguyen, L.; Prescianotto-Baschong, C.; Huygen, K.; Klebl, B.; Thompson, C.; Bacher, G. \& Pieters, J. (2004). Protein kinase G from pathogenic mycobacteria promotes survival within macrophages. Science, Vol.304, No.5678, (June 2004), pp. 1800-1804

Wong, K. \& Isberg, R. (2003). Arf6 and phosphoinositol-4-phosphate-5-kinase activities permit bypass of the Rac1 requirement for beta1 integrin-mediated bacterial uptake. Journal of Experimental Medicine, Vol.198, No.4, (August 2003), pp. 603-614

Wong, D.; Bach, H.; Sun, J.; Hmama, Z. \& Av-Gay, Y. (2011). Mycobacterium tuberculosis protein tyrosine phosphatase (PtpA) excludes host vacuolar- $\mathrm{H}^{+}$-ATPase to inhibit phagosome acidification. Proceedings of the National Academy of Science United States of America, Vol.108, No.48, (November 2011), pp. 19371-19376

Wurzner, R. (1999). Evasion of pathogens by avoiding recogmition or eradication by complement, in part via molecular mimicry. Molecular Immunology, Vol.36, No.4-5, (March-April 1999), pp. 249-260

Yamamoto, M.; Sato, S.; Hemmi, H.; Hoshino, K.; Kaisho, T.; Sanjo, H. et al. (2003a). Role of adaptor TRIF in the MyD88-independent toll-like receptor signalling pathway. Science, Vol.301, No.5633, (August 2003), pp. 640-643

Yamamoto M.; Sato, S.; Hemmi, H.; Uematsu, S.; Hoshino, K.; Kaisho, T. et al. (2003b). TRAM is specifically involved in the Toll-like receptor 4-mediated MyD88independent signalling pathway. Nature Immunology, Vol.4, No.11, (November 2003), pp. 1144-1150

Yamauchi, K.; Choi, I.; Lu, H.; Ogiwara, H.; Graham, D. \& Yamaoka, Y. (2008). Regulation of IL-18 in Helicobacter pylori infection. Journal of Immunology, Vol.180, No.2, (January 2008), pp. 1207-1216

Yates, R.; Hermetter, A. \& Russell, D. (2005). The kinetics of phagosome maturation as a function of phagosome/lysosome fusion and acquisition of hydrolytic activity. Traffic, Vol.6, No.5, (May 2005), pp. 413-420

Zhou, B.; He, Y.; Zhang, X.; Xu, J.; Luo, Y.; Wang, Y., Franzblau, S.; Yang, Z.; Chan, R.; Liu, Y.; Zheng, J. \& Zhang, Z. (2010). Targeting Mycobacterium protein tyrosine 
phosphatase B for antituberculosis agents. Proceedings of the National Academy of Science United States of America, Vol.107, No.10, (March 2010), pp. 4573-4578

Zumbihl, R.; Aepfelbacher, M.; Andor, A.; Jacobi, C.; Ruckdeschel, K.; Rouot, B. \& Heesemann, J. (1999). The cytotoxin YopT of Yersinia enterolitica induces modification and cellular redistribution of the small GTP-binding protein RhoA. Journal of Biological Chemistry, Vol.274, No.41, (October 1999), pp. 29289-29293 


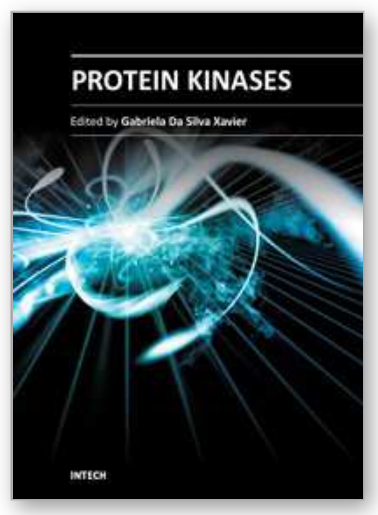

\author{
Protein Kinases \\ Edited by Dr. Gabriela Da Silva Xavier
}

ISBN 978-953-51-0640-1

Hard cover, 484 pages

Publisher InTech

Published online 05, June, 2012

Published in print edition June, 2012

Proteins are the work horses of the cell. As regulators of protein function, protein kinases are involved in the control of cellular functions via intricate signalling pathways, allowing for fine tuning of physiological functions. This book is a collaborative effort, with contribution from experts in their respective fields, reflecting the spirit of collaboration - across disciplines and borders - that exists in modern science. Here, we review the existing literature and, on occasions, provide novel data on the function of protein kinases in various systems. We also discuss the implications of these findings in the context of disease, treatment, and drug development.

\title{
How to reference
}

In order to correctly reference this scholarly work, feel free to copy and paste the following:

Horacio Bach (2012). Role of Kinases and Phosphatases in Host-Pathogen Interactions, Protein Kinases, Dr. Gabriela Da Silva Xavier (Ed.), ISBN: 978-953-51-0640-1, InTech, Available from:

http://www.intechopen.com/books/protein-kinases/role-of-kinases-and-phosphatases-in-host-pathogeninteractions

\section{INTECH}

open science | open minds

\section{InTech Europe}

University Campus STeP Ri

Slavka Krautzeka 83/A

51000 Rijeka, Croatia

Phone: +385 (51) 770447

Fax: +385 (51) 686166

www.intechopen.com

\section{InTech China}

Unit 405, Office Block, Hotel Equatorial Shanghai

No.65, Yan An Road (West), Shanghai, 200040, China

中国上海市延安西路65号上海国际贵都大饭店办公楼405单元

Phone: +86-21-62489820

Fax: +86-21-62489821 
(C) 2012 The Author(s). Licensee IntechOpen. This is an open access article distributed under the terms of the Creative Commons Attribution 3.0 License, which permits unrestricted use, distribution, and reproduction in any medium, provided the original work is properly cited. 